\title{
Protective Alumina Coatings Prepared by Aerosol Deposition on Magnetocaloric Gadolinium Elements
}

\author{
Matej Sadl ${ }^{1,2}$,Urban Tomc ${ }^{3}$,Uros Prah ${ }^{1,2}$ and Hana Ursic ${ }^{1,2}$ \\ ${ }^{1}$ Jozef Stefan Institute, Ljubljana, Slovenia \\ ${ }^{2}$ Jozef Stefan International Postgraduate School, Ljubljana, Slovenia \\ ${ }^{3}$ University of Ljubljana, Faculty of Mechanical Engineering, Ljubljana, Slovenia
}

\begin{abstract}
In this work the preparation of a protective insulating alumina coating on magnetocaloric gadolinium elements was investigated. In order to prepare a dense ceramic coating at room temperature the aerosol deposition technique was used. The study reveals that the powder morphology and particle size are important parameters that influence the deposition efficiency, powder packing and consequently also the density and functional properties of the alumina coating. The optimal powder pre-deposition treatment includes heating the powder to $1150^{\circ} \mathrm{C}$, followed by milling. The deposition of this powder resulted in the preparation of dense alumina coatings with a low specific electrical conductivity of $6.4 \cdot 10^{-14} \Omega^{-1} \mathrm{~m}^{-1}$.
\end{abstract}

\section{Korundna zaščita magnetokaloričnih hladilnih elementov pripravljena z metodo nanašanja delcev $v$ curku aerosola}

\begin{abstract}
Izvleček: V članku smo preučevali pripravo zaščitnih korundnih prevlek za magnetokalorične hladilne elemente iz gadolinija. Prevleke smo pripravili z metodo za nanašanje delcev v curku aerosola, ki omogoča pripravo gostih prevlek že pri sobni temperaturi. Ugotovili smo, da morfologija prahu in velikost delcev pomembno vplivata na učinkovitost nanosa in pakiranje prahu ter posledično tudi na gostoto in funkcionalne lastnosti prevlek. Optimalni postopek obdelave prahu pred nanašanjem vključuje termično obdelavo prahu pri $1150^{\circ} \mathrm{C}$ ter mletje v planetarnem mlinu. Iz predhodno obdelanega prahu je mogoče pripraviti goste korundne prevleke $z$ nizko specifično električno prevodnostjo, ki znaša $6 \cdot 4 \cdot 10^{-14} \Omega^{-1} \mathrm{~m}^{-1}$.
\end{abstract}

Ključne besede: korundne zaščitne prevleke, nanašanje delcev v curku aerosola, magnetokalorični gadolinij

${ }^{*}$ Corresponding Author's e-mail: matej.sadl@ijs.si

\section{Introduction}

Magnetocaloric (MC) refrigeration technology is gaining importance as it represents an alternative to conventional vapor-compression technology for specific applications $[1,2]$. One of the best candidates for a MC material operating at around room temperature is gadolinium, with an adiabatic temperature change of $\Delta T_{\text {ad }}$ $\sim 12 \mathrm{~K}$ for a magnetic field change of $5 \mathrm{~T}$ at a temperature of $294 \mathrm{~K}$ [3].
Many of the MC refrigeration prototypes are based on the principle of active magnetic regeneration. This principle is suitable for implementing in large refrigeration devices, where also an efficient heat-exchange system is needed [2]. The heat-exchange media are typically water or water-based fluids, which can cause the gadolinium working elements to corrode [4].

Caloric research is also developing towards the use of MC cooling technology in electronics. In this case, for the 
efficient transfer of heat, more sophisticated heat-management systems are needed, such as thermal switches or thermal diodes $[5,6]$. One way to activate these thermal switches is by using an electric field, which can be detrimental for the working elements. In addition to problems with the oxidation of gadolinium, new challenges appear regarding the protection of the gadolinium elements against possible electrical breakdown. These problems can be solved by the deposition of a protective layer on the top of the gadolinium element.

Polycrystalline aluminum oxide $\left(\mathrm{Al}_{2} \mathrm{O}_{3}\right)$, more often referred as alumina, is an abundant and one of the most widely used ceramic materials. Alumina is used in versatile applications due to its excellent properties, e.g., high electrical insulation, heat resistance, chemical inertness and high mechanical hardness. Those properties make alumina one of the best materials for protecting materials against harsh environments [7-10]. In order to deposit a protective alumina layer on gadolinium metal an aerosol deposition (AD) method can be used.

$A D$ is a spray-coating process for producing dense thick films, where the deposition mechanism is based on the collision of fine particles with the substrate's surface. A powder is mixed with a carrier gas to form an aerosol, which is then ejected through a nozzle and deposited onto the substrate under vacuum $[11,12]$. The AD process occurs at room temperature; thus this method makes it possible to combine materials that are normally not stable or compatible at high temperatures. Aerosol-deposited alumina thick films exhibit excellent corrosion resistance [13] and electrical insulation [14]. For example, they have a high electrical breakdown strength, exceeding $600 \mathrm{kV} \cdot \mathrm{cm}^{-1}[14,15]$. These films can also be used as anti-scratch and anti-smudge coatings due to their promising mechanical properties [12] The high hardness of AD alumina films (between 1100 HV and 1800 HV $[13,16-18])$, which is comparable with the hardness of bulk alumina, and a good adhesive strength of $64 \mathrm{MPa}$ [19] were reported.

In this work the AD of a protective alumina coating on gadolinium cooling elements was investigated. The properties of the alumina powder are of high importance for efficient deposition and good particle packing. Therefore, special attention was given to the predeposition treatment of the starting powder in order to prepare a dense insulating protection layer.

\section{Materials and Methods}

For $\mathrm{AD}$ a raw $\mathrm{Al}_{2} \mathrm{O}_{3}$ commercial powder $\mathrm{AL}-160 \mathrm{SG} 3$, Showa Denko, Japan (further denoted as the R powder) and its two modifications; heated $(\mathrm{H})$ powder as well as heated and milled (HM) powder were used. The $\mathrm{H}$ and $\mathrm{HM}$ powders were thermally treated in a chamber furnace (Custom-made, Terna, Slovenia) at $1150{ }^{\circ} \mathrm{C}$ for $1 \mathrm{~h}$ (with $5 \mathrm{~K} \cdot \mathrm{min}^{-1}$ heating and cooling rates). These annealing conditions were chosen based on the sintering curve of pressed $\mathrm{Al}_{2} \mathrm{O}_{3}$ pellets at the point where the densification starts $\left(1150{ }^{\circ} \mathrm{C}\right)$. The HM powder was after annealing milled in a planetary mill (PM400, Retsch, Germany) at $200 \mathrm{~min}^{-1}$ for $1 \mathrm{~h}$ using yttria-stabilized-zirconia milling balls in iso-propanol as a liquid medium. The particle size distribution of the powders was determined by using a light-scattering granulometer ( $\mathrm{S} 3500$, Microtrac, USA).

The aerosol deposition equipment was provided by Invertech, Germany. The commercial gadolinium substrates (Metall Rare Earth Limited, Hong Kong) were used. A scheme of the AD apparatus is shown in Figure 1. The process parameters during the $A D$ were kept the same for the deposition of all three powders (shown in Table 1).

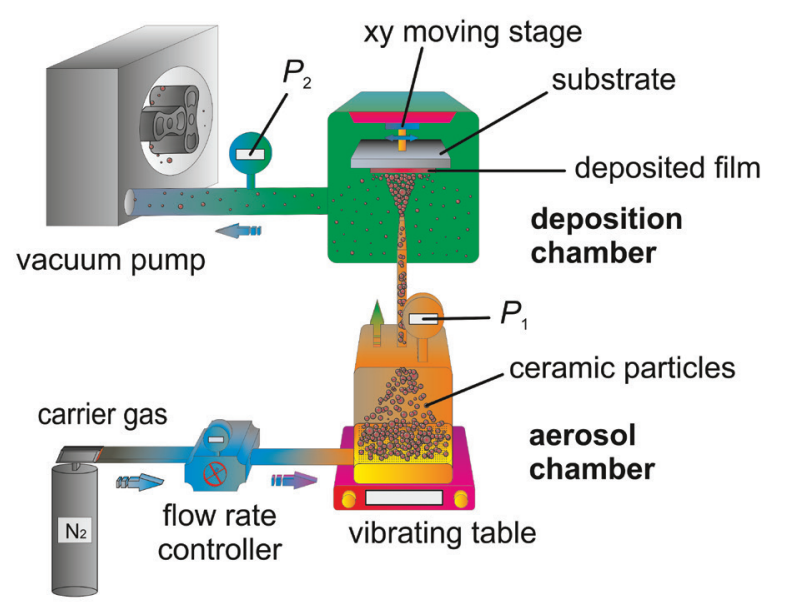

Figure 1: Scheme of the AD apparatus.

Table 1: Process parameters used during the AD.

\begin{tabular}{|l|l|}
\hline \multicolumn{2}{|l|}{ Process parameters } \\
\hline$P_{1}$ & $150-250 \mathrm{mbar}$ \\
\hline$P_{2}$ & $0.2-0.5 \mathrm{mbar}$ \\
\hline Nozzle geometry (slit size) & $(0.5 \cdot 10) \mathrm{mm}^{2}$ \\
\hline Carrier gas species & $\mathrm{N}_{2}$ \\
\hline Gas flow rate & $4 \mathrm{~L} \cdot \mathrm{min}^{-1}$ \\
\hline $\begin{array}{l}\text { Distance between nozzle } \\
\text { and substrate }\end{array}$ & $5 \mathrm{~mm}$ \\
\hline Sweep speed & $5 \mathrm{~mm} \cdot \mathrm{s}^{-1}$ \\
\hline
\end{tabular}

The thickness and root-mean-square roughness $\left(R_{\mathrm{q}}\right)$ of the prepared layers were evaluated from line profiles 
measured with a contact profilometer (DektakXT, Bruker, USA) by using the software Vision64 (Bruker, USA). The thickness was evaluated from the step height of the film after curvature removal using a quartic polynomial. $R_{\mathrm{q}}$ was evaluated from the roughness profile obtained after filtering the total profile using Gaussian regression (cut off $0.08 \mathrm{~mm}$ ).

The alumina powders and thick films were microstructurally analyzed using a field-emission scanning electron microscope (FE-SEM, JSM 7600F, Jeol, Japan). The microstructural analyses of the thick films were made on polished cross-sections.

Prior to the electrical characterization, gold electrodes with a diameter of $1.5 \mathrm{~mm}$ were deposited on the top of the film's surface by magneton sputtering (Cinquepascal SRL, Italy). The current density-electric field $(J-E)$ measurements were made using a Keithley 237 high-voltage-source measurement unit (Keithley Instruments, USA). Each sample was exposed to step-like voltages from negative to positive polarity in the range up to $150 \mathrm{kV} \cdot \mathrm{cm}^{-1}$. The whole measurement consisted of seven equal field steps. The specific direct current $(D C)$ conductivity $\left(\sigma_{D C}\right)$ was obtained at $150 \mathrm{kV} \cdot \mathrm{cm}^{-1}$, assuming Ohm's law.

\section{Results}

In order to evaluate the characteristics of all three powders used for the deposition experiment we first examined the particle size distribution. Figure 2 shows the particle size distributions (solid line) and the corresponding cumulative curves (dashed line). In the inset the $d_{10^{\prime}} d_{50}$ and $d_{90}$ values for each powder are collected. According to the literature, the optimal particle size for the aerosol deposition of ceramic powders ranges between $0.2 \mu \mathrm{m}$ and $2 \mu \mathrm{m}[11,12]$. In the R and HM

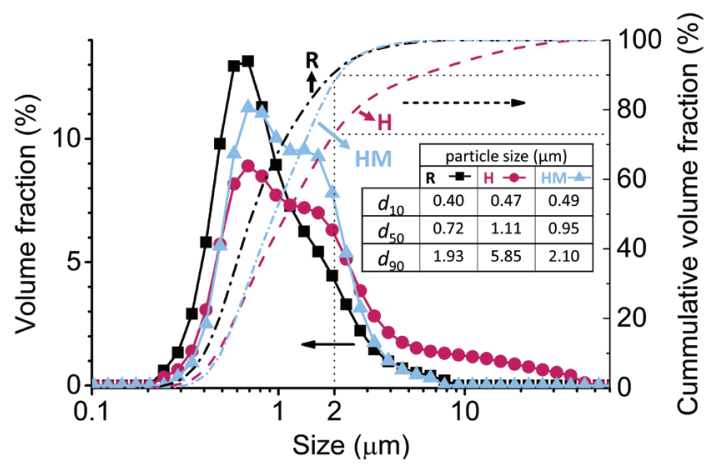

Figure 2: Particle size distributions (solid line) and the corresponding cumulative curves (dashed line) of $\mathrm{R}, \mathrm{H}$ and HM powders. The $d_{10^{\prime}} d_{50}$ and $d_{90}$ values of all three powders are presented in the inset table. powders, 90 vol\% of the particles fit well in this range, while in the $\mathrm{H}$ powder the percentage of such particles is smaller (i.e., 75 vol\%). This indicates that the $\mathrm{R}$ and HM powders could exhibit better deposition characteristics in comparison to the $\mathrm{H}$ powder.

The FE-SEM micrographs of the powders are shown in Figure 3. By comparing the $\mathrm{R}$ and $\mathrm{H}$ powders, it is clear that in the $\mathrm{R}$ powder the particles are sharper and more irregularly shaped. The heat treatment causes particle coarsening in terms of merging the small agglomerated particles together and creating necks between them. After heating the particle surface appears smoother.
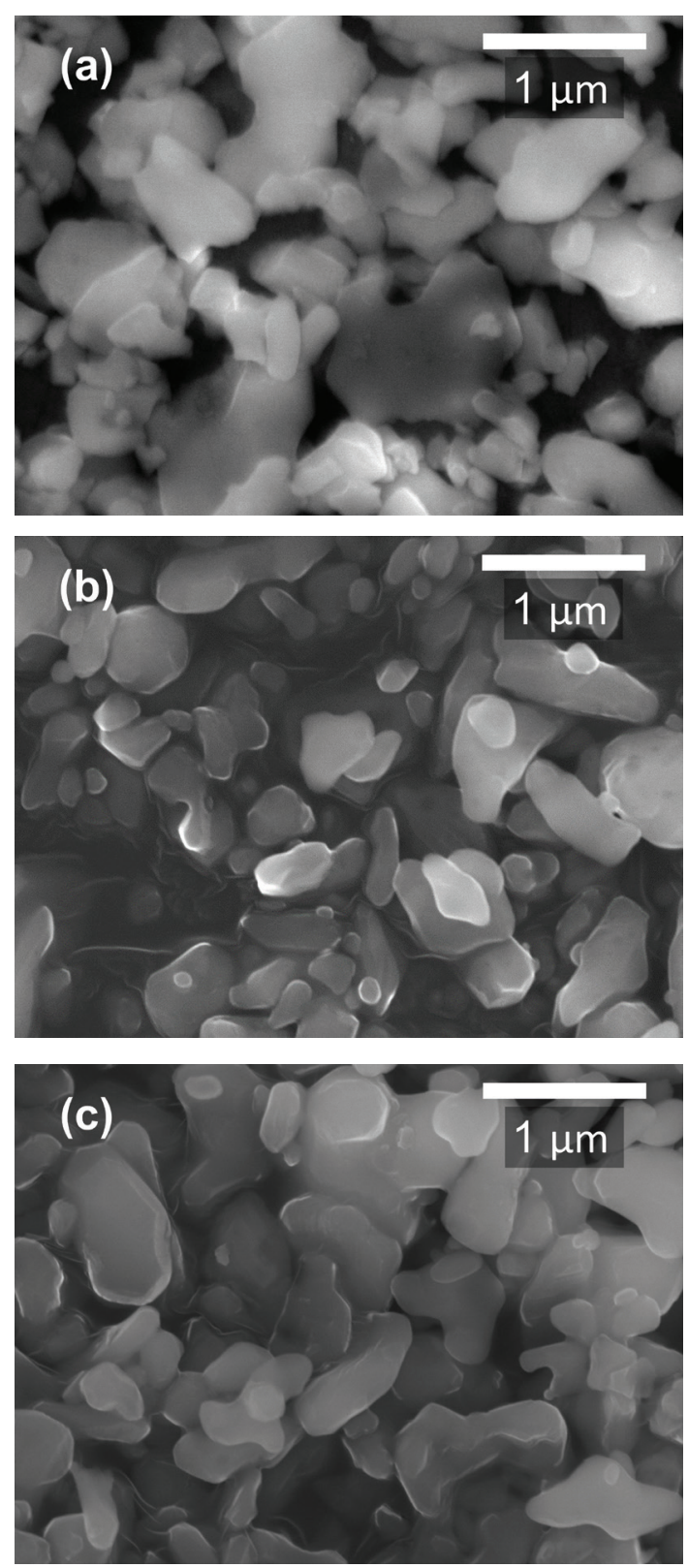

Figure 3: Secondary-electron FE-SEM images of (a) R, (b) $\mathrm{H}$ and (c) HM powders. 
The additional milling treatment reduces the average particle size (HM powder). However, compared to the particles of $\mathrm{R}$ powder, the surface of the HM powder remains smooth and more uniform in size.

After the examination of the powder, all three types of powders were deposited on polished gadolinium elements. The line profiles of the films deposited on the substrates are shown in Figure 4. The $\mathrm{H}$ powder has the lowest deposition rate, which is reflected in the very small film thickness $(\sim 0.9 \mu \mathrm{m})$ and the high surface roughness $\left(R_{\mathrm{q}} \sim 0.2 \mu \mathrm{m}\right)$. On the other hand, the $\mathrm{R}$ and HM powders were much more effectively deposited on the gadolinium element, resulting in films with thicknesses of $10.9 \mu \mathrm{m}$ and $6.4 \mu \mathrm{m}$, respectively. Also, the roughness of both films was smaller $\left(R_{q} \sim 0.1 \mu \mathrm{m}\right)$ compared to the roughness of the film prepared from the $\mathrm{H}$ powder.

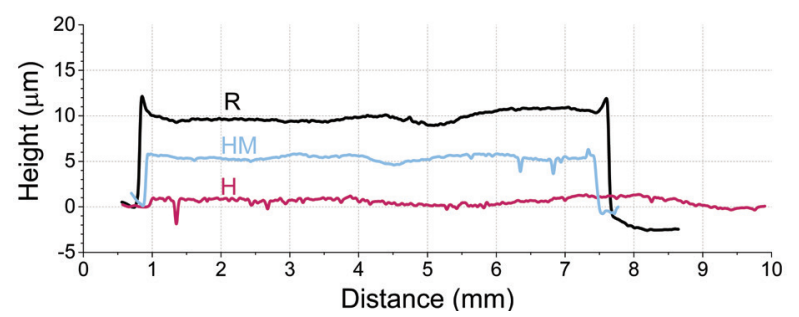

Figure 4: Line profiles of deposited alumina layers on gadolinium elements.

To investigate the electrical conductivity of alumina coatings, $J-E$ measurements were performed at room temperature (Figure 5). The films prepared from the $\mathrm{H}$ powder (thickness $<1 \mu \mathrm{m}$ ) were electrically conductive, and the leakage current was too high to perform the measurements. This enhanced conductivity is most probably the consequence of the non-uniform deposition of the $\mathrm{H}$ powder onto the gadolinium substrate

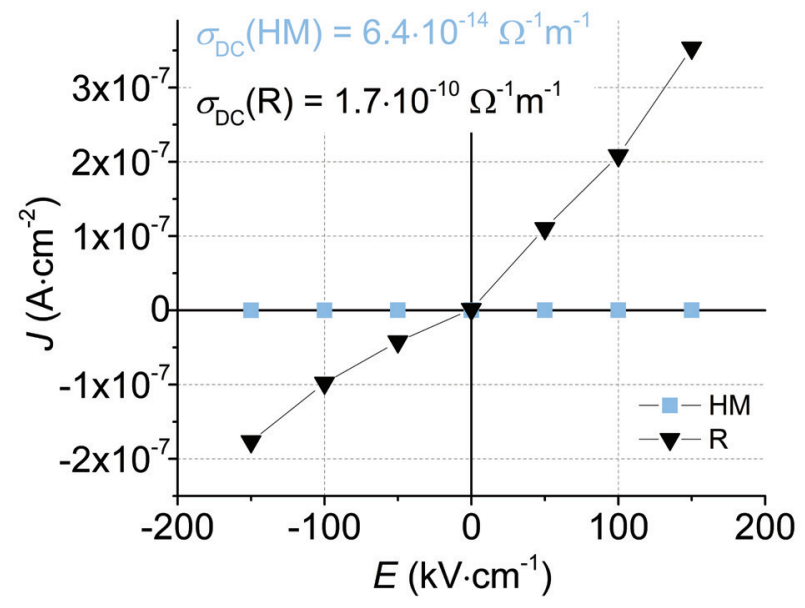

Figure 5: $J$ - $E$ curves and calculated $\sigma_{D C}$ values of thick films prepared from $\mathrm{R}$ and $\mathrm{HM}$ powders.
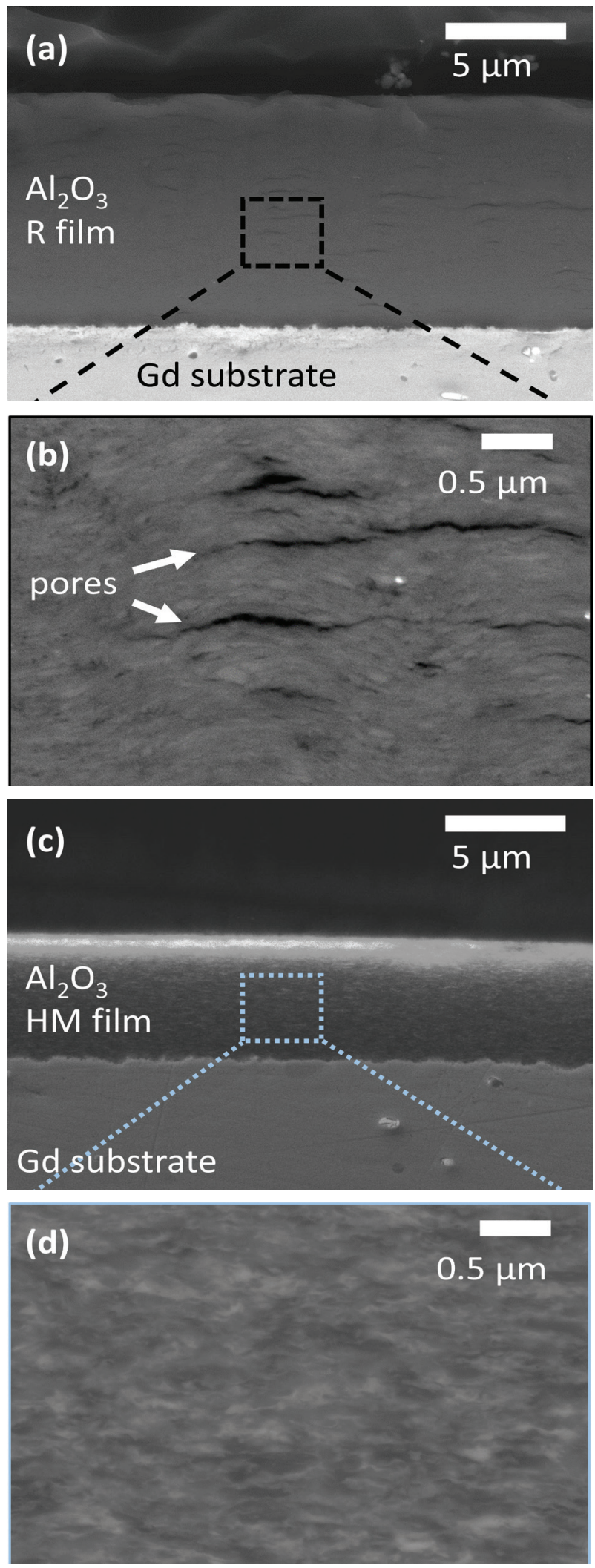

Figure 6: FE-SEM cross-sectional images of thick films prepared from $(a, b) \mathrm{R}$ and $(c, d) H M$ powders. The micrographs in Figures $(a, c)$ and $(b, d)$ were taken with a secondary-electron and backscattered-electron detector, respectively. 
(Figure 4). The lowest $\sigma_{D C}$ was obtained in the films prepared from the HM powder, i.e., $6.4 \cdot 10^{-14} \Omega^{-1} \mathrm{~m}^{-1}$, which is comparable to the conductivity of the sintered bulk alumina [20]. The films prepared from the $\mathrm{R}$ powder possess a significantly (4 orders of magnitude) higher $\sigma_{D^{\prime}}$ i.e., $1.7 \cdot 10^{-10} \Omega^{-1} \mathrm{~m}^{-1}$.

In order to understand why alumina coatings prepared from $\mathrm{R}$ powder are more conductive than those prepared from HM powder, the FE-SEM microstructural analyses of those films in cross-section were performed. The images of the R and HM films are shown in Figures $6(a, b)$ and $(c, d)$, respectively. Both the $R$ and HM films exhibit good adhesion to the gadolinium substrate. In Figure $6(\mathrm{a}, \mathrm{c})$ a larger thickness of the R film in comparison to the HM film (in agreement with line profiles in Figure 4) is revealed, indicating better deposition rate of the $\mathrm{R}$ powder. Larger thickness of the layer can also lead to higher probability for defects in microstructures, which could lead to higher conductivity of the sample. Furthermore, a closer look of R film (Figure 6 (b)) reveals micro-sized pores elongated in the horizontal direction. Similar elongated pores were already reported in aerosol deposited alumina films [13]. Such microstructure is most probably the main reason for the high electrical conductivity of these films. On the other hand, the films prepared from the HM powder (Figure 6 (d)) are very dense and pore-free. This indicates better packing of the HM powder during the deposition, in comparison to the $\mathrm{R}$ powder, which could be related to the more smooth and uniform size of HM powder. The films prepared from the HM powder possess the lowest electrical conductivity and are therefore the most promising for the protection and electrical insulation of the magnetocaloric elements.

\section{Summary and Conclusions}

To summarize, the processing of alumina protective layers on magnetocaloric gadolinium elements was studied. The protective coating was prepared by the aerosol deposition technique, which enables the preparation of dense films at room temperature. In order to study the influence of powder size and morphology on the deposition rate, different pre-deposition treatments of the powders were used. The optimal powder treatment includes heating the powder to $1150{ }^{\circ} \mathrm{C}$ for $1 \mathrm{~h}$ and subsequent milling in a planetary mill. The deposition of such thermally treated and milled powder yielded a dense, few-micrometers-thick alumina protective layer with promising electrical insulation properties (a specific DC conductivity below $10^{-13} \Omega^{-1} \mathrm{~m}^{-1}$ ).

\section{Acknowledgments}

The authors thank the financial support from the Director's fund 2017 - ULTRACOOL, Jožef Stefan Institute and the Slovenian Research Agency (projects J2-9253, J21738-1, Z2-9247, young researcher project PR-08977 and research core funding No. P2-0105). Technical support by Remy Lecomte (Erasmus+ programme) is gratefully acknowledged.

\section{Conflicts of Interest}

The authors declare no conflict of interest. The founding sponsors had no role in the design of the study; in the collection, analyses, or interpretation of data; in the writing of the manuscript, and in the decision to publish the results.

\section{References}

1. A. Kitanovski, U. Plaznik, U. Tomc, and A. Poredoš, "Present and future caloric refrigeration and heatpump technologies," Int. J. Refrig., vol. 57, pp. 288298, 2015, https://doi.org/10.1016/j.jirefrig.2015.06.008.

2. A. Kitanovski, J. Tušek, U. Tomc, U. Plaznik, M. Ožbolt, and A. Poredoš, Magnetocaloric Energy Conversion. Cham: Springer International Publishing, 2015.

https://doi.org/10.1007/978-3-319-08741-2

3. S. Y. Dan'kov, A. M. Tishin, V. K. Pecharsky, and K. A. Gschneidner, "Magnetic phase transitions and the magnetothermal properties of gadolinium," Phys. Rev. B, vol. 57, no. 6, pp. 3478-3490, 1998, https://doi.org/10.1103/PhysRevB.57.3478.

4. J. Forchelet, L. Zamni, S. El Maudni El Alami, J. Hu, M. Balli, and O. Sari, "Corrosion behavior of gadolinium and La-Fe-Co-Si compounds in various heat conducting fluids," Int. J. Refrig., vol. 37, no. 1, pp. 307-313, 2014,

https://doi.org/10.1016/j.ijrefrig.2013.09.021.

5. G. Wehmeyer, T. Yabuki, C. Monachon, J. Wu, and C. Dames, "Thermal diodes, regulators, and switches: Physical mechanisms and potential applications," Appl. Phys. Rev., vol. 4, no. 4, 2017, https://doi.org/10.1063/1.5001072.

6. A. Kitanovski and P. W. Egolf, "Innovative ideas for future research on magnetocaloric technologies," Int. J. Refrig., vol. 33, no. 3, pp. 449-464, May 2010, https://doi.org/10.1016/j.jirefrig.2009.11.005.

7. T. Lampke et al., "Corrosion and wear behavior of alumina coatings obtained by various methods," 
Mater. Sci., vol. 46, no. 5, pp. 591-598, 2011, https://doi.org/10.1007/s11003-011-9328-2.

8. E. J. Young, E. Mateeva, J. J. Moore, B. Mishra, and M. Loch, "Low pressure plasma spray coatings," Thin Solid Films, vol. 377-378, pp. 788-792, 2000, https://doi.org/10.1016/S0040-6090(00)01452-8.

9. T. Lampke et al., "Alumina coatings obtained by thermal spraying and plasma anodising - A comparison," Surf. Coatings Technol., vol. 206, no. 7, pp. 2012-2016, 2011, https://doi.org/10.1016/j.surfcoat.2011.09.006.

10. O. Sarikaya, "Effect of the substrate temperature on properties of plasma sprayed $\mathrm{Al}_{2} \mathrm{O}_{3}$ coatings," Mater. Des., vol. 26, no. 1, pp. 53-57, 2005, https://doi.org/10.1016/j.matdes.2004.04.005.

11. J. Akedo, "Room temperature impact consolidation (RTIC) of fine ceramic powder by aerosol deposition method and applications to microdevices," J. Therm. Spray Technol., vol. 17, no. 2, pp. 181-198, 2008, https://doi.org/10.1007/s11666-008-9163-7.

12. D. Hanft, J. Exner, M. Schubert, T. Stöcker, P. Fuierer, and R. Moos, "An overview of the Aerosol Deposition method: Process fundamentals and new trends in materials applications," J. Ceram. Sci. Technol., vol. 6, no. 3, pp. 147-181, 2015, https://doi.org/10.4416/JCST2015-00018.

13. N. Seto, K. Endo, N. Sakamoto, S. Hirose, and J. Akedo, "Hard a- $\mathrm{Al}_{2} \mathrm{O}_{3}$ Film Coating on Industrial Roller Using Aerosol Deposition Method," J. Therm. Spray Technol., vol. 23, no. 8, pp. 1373-1381, 2014, https://doi.org/10.1007/s11666-014-0135-9.

14. H. M. Cho and H. J. Kim, "Metal-core printed circuit board with alumina layer by aerosol deposition process," IEEE Electron Device Lett., vol. 29, no. 9, pp. 991-993, 2008, https://doi.org/10.1109/LED.2008.2001633.

15. Y. Sato, Y. Uemichi, K. Nishikawa, and S. Yoshikado, "Fabrication of $\mathrm{Al}_{2} \mathrm{O}_{3}$ Films Using Aerosol Deposition Method and Their Characterization," IOP Conf. Ser. Mater. Sci. Eng., vol. 18, no. 9, p. 092056, 2011, https://doi.org/10.1088/1757-899X/18/9/092056.

16. D. W. Lee, H. J. Kim, Y. N. Kim, M. S. Jeon, and S. M. Nam, "Substrate hardness dependency on properties of $\mathrm{Al}_{2} \mathrm{O}_{3}$ thick films grown by aerosol deposition," Surf. Coatings Technol., vol. 209, pp. 160-168, 2012,

https://doi.org/10.1016/j.surfcoat.2012.08.012.

17. H.-J. Kim, Y.-H. Kim, J.-W. Lee, S.-M. Nam, Y. J. Yoon, and J.-H. Kim, "Residual Stress Relief in $\mathrm{Al}_{2} \mathrm{O}_{3}-$ PolyTetra-Fluoro-Ethylene Hybrid Thick Films for Integrated Substrates Using Aerosol Deposition," J. Nanoelectron. Optoelectron., vol. 7, no. 3, pp. 287291, 2012, https://doi.org/10.1166/jno.2012.1305.
18. M. Lebedev, J. Akedo, and T. Ito, "Substrate heating effects on hardness of an $\mathrm{a}-\mathrm{Al}_{2} \mathrm{O}_{3}$ thick film formed by aerosol deposition method," J. Cryst. Growth, vol. 275, no. 1-2, pp. e1301-e1306, 2005, https://doi.org/10.1016/j.jcrysgro.2004.11.109.

19. H. Hatono, T. Ito, K. Iwata, and J. Akedo, "Multilayer Construction with Various Ceramic Films for Electronic Devices Fabricated by Aerosol Deposition," Int. J. Appl. Ceram. Technol., vol. 3, no. 6, pp. 419427, 2006, https://doi.org/10.1111/j.1744-7402.2006.02109.x.

20. W. D. Kingery, H. K. Bowen, and D. R. Uhlmann, Introduction to Ceramics, no. 2. London:Wiley, 1976. https://doi.org/10.1007/978-4-431-54108-0 1

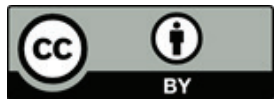

Copyright $\odot 2019$ by the Authors. This is an open access article distributed under the Creative Commons Attribution (CC BY) License (https://creativecommons.org/licenses/by/4.0/), which permits unrestricted use, distribution, and reproduction in any medium, provided the original work is properly cited.

Arrived: 26. 09. 2019

Accepted: 08. 11. 2019 